\section{Betimelig om sykefravær}

Sandvin J, red.

Arbete, sjukdom och moral

Om sjukskrivning och vägen tilbaka till arbetet. 224 s, ill. Lund: Studentlitteratur, 2009.

Pris SEK 223

ISBN 978-91-44-05359-2

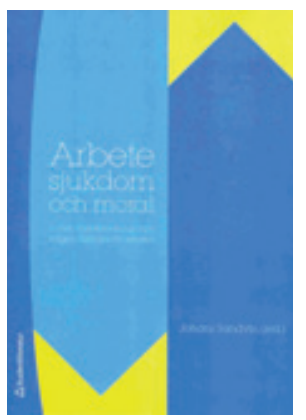

Dette er den svenske utgaven av en bok som kom på norsk i 2008 med norsk redaktør. Den er like aktuell i år som i fjor og vil nok være det til neste år også fordi den utfordrer antikverte forestil-

linger om sykefravær som har vist seg utrolig seiglivede.

Premisset er at sykefraværet stiger på tross av velmente kampanjer gjennom mange år, og man hevder at grunnen til manglende suksess er at problemene omkring sykefravær og retur til arbeid er dårlig forstått. Det siste tror jeg er riktig. Men jeg er ikke uten videre enig i premisset om stadig stigende sykefravær. Det som stiger, er utgiftene til sykefravær. I siste statsbudsjett er det plusset på fire milliarder. Sykefraværet, slik NHO har målt det siden 1973 og slik Statistisk sentralbyrå gjør det i dag, har vist seg forbausende konstant, til tross for oppslag i Aftenposten og Dagbladet denne høsten om det motsatte.

Boken starter med et oppgjør med det den kaller den skolemedisinske forståelsen av sykefravær og rehabilitering, ført i pennen av lege og idéhistoriker Georg Espolin Johnson. I et leseverdig og informativt kapittel hevder han blant mye annet at vi må bort fra et essensialistisk sykdomsbegrep, altså en oppfatning av sykdommen som et selvstendig objekt som kan behandles (fjernes). Vi må heller vurdere funksjonssvikt, forstått som sviktende forsørgelsesevne, uavhengig av biologiske funn. Han mener det vil bli tungt å få langtidssykmeldte tilbake i arbeid før vi kvitter oss med forestillingen om at alle som ikke har en sykdom diagnostisert av lege, er $\mathrm{i}$ stand til å fungere $\mathrm{i}$ arbeidslivet om de bare vil.

Redaktøren har så et kapittel hvor han utfordrer fire myter: om dårlig arbeidsmoral, om problemets individbundne karakter, om singulære forklaringer og singulære løsninger, det vil si én dominerende forklaring og én dominerende løsning.

Noen kapitler deretter omhandler lovende erfaringer med alternative tilnærminger til rehabilitering, høstet gjennom et EU-prosjekt kalt Equal.

I den siste delen oppsummeres disse erfaringene, og det pekes på mulige veier frem- over. Kompleksiteten i problemet slik det oppleves av langtidssykmeldte og behovet de har for å bli tatt på alvor fremheves. Det anføres å være stor fare for «mismatch» mellom livsverdenen og systemverdenen (i Habermas' forstand). For å bøte på dette må det anlegges et helhetsperspektiv på årsakene og et individuelt perspektiv på løsningene, og den sykmeldte må ledes gjennom behandlings- og rehabiliteringssystemet av en personlig koordinator. Siste kapittel handler om hvordan dette kan omsettes i praktisk handling.

Jeg har hatt glede av Arbete, sjukdom och moral og tror alle, både leger og andre som steller med sykmelding og utstøtingsproblemer, vil ha det. Den anbefales spesielt til rikspolitikere med ansvar for regelverket på dette området.

\section{Håkon Lasse Leira}

Arbeidsmedisinsk avdeling

St. Olavs hospital

\section{Med håp mot det vonde}

Roalkvam G, Johannessen JV, Dahl PA, et al. Sammen om livet

Ha det meningsfylt i det meningsløse.

168 s, ill. Sandnes: Kulturhuset forlag, 2008.

Pris NOK 348

ISBN 978-82-92579-11-4

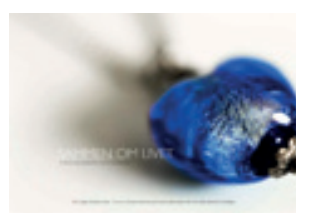

Dette er en spesiell bok, jeg har aldri lest noe liknende. Derfor har jeg lest den flere ganger, latt den ligge,

bladd i den og latt den modne i meg.

Utgangspunktet var at Berit fikk kreft og kjempet mot sykdommen sammen med mannen Arvid og de tre barna. De fikk tilbud om en «bloggespalte» i Stavanger Aftenblad, og sammen skrev de om sykdommen, om sine gode og vonde erfaringer med helsetjenesten og om sine opplevelser på sine respektive arbeidsplasser, på skolen og med slektninger, venner og bekjente. De fikk stor respons av leserne, både innlegg i avisen og brev. Etter at Berit var død, bestemte Arvid seg for å lage en vakker bok til inntekt for kreftomsorgen.

Resultatet er blitt en praktutgivelse med korte tekster av kjente forfattere, som presten Per Arne Dahl og legen Jan Vincents Johannessen, med poesi og med fotografier av Signe C. Urdal og malerier av Gunn L. Gaarden. Det hele er satt sammen på en måte som beskriver sykdommen, tanker, følelser og alle relasjonene underveis på veien mot døden. Det er blitt en fortelling om følelser, om nærhet, om varme og også om humor. Menneskene er forskjellige, og her belyses disse forskjellene gjennom forløpet av sykdommen. Men menneskene er også grunnleggende like når det kommer til stykket. Derfor er det det allmennmenneskelige som fanger meg.

Hvem kan ha glede og nytte av denne utgivelsen? Det er mange, selv om det kreves vilje til å ta budskapet innover seg. Det er noen få bitre ord om mangelfull kommunikasjon og manglende samarbeid i helsetjenesten og om følelsesløse leger, men heldigvis har de aller fleste i helsetjenesten forstått og møtt pasienten og de pårørende. Det gjaldt også skolen, etter at den hadde fått besøk av en kreftsykepleier. Men det er tydelig at både helsetjenesten og skolen har noe å lære her. Og det gjelder også folk flest, for vi må møte disse pasientene og deres pårørende på en åpen og god måte. Ikke stikk deg vekk selv om du ikke vet hva du skal si. Vis følelser og omsorg.

Sammen om livet inneholder nesten ikke tekst, bortsett fra sitater og poesi. Bildene er vakre - hele boken er et kunstverk. Jeg anbefaler den til alle, også til alt helsepersonell.

Peter F. Hjort

Blommenholm

\section{Uviktig om viktig tema}

Kiess W, Chernausek SD,

Hokken-Koelega ACS, red.

Small for gestational age

Causes and consequences. 167 s, tab, ill.

Basel: Karger, 2009. Pris CHF 158

ISBN 978-3-8055-8657-3

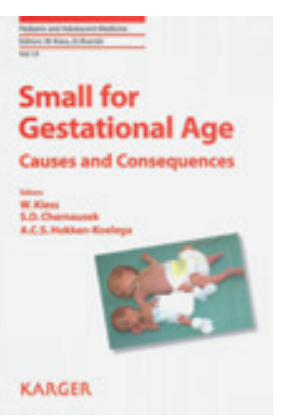

Barn med lav vekt i forhold til svangerskapsvarigheten (small for gestational age, SGA) har lenge vært en viktig gruppe innen svangerskapsomsorg og nyfødtmedisin. I de senere år har også de helsemessige konsekvensene $\mathrm{i}$ voksen alder av veksten i mors liv kommet i søkelyset. En bok om emnet burde være potensielt viktig både for klinikere og samfunnsmedisinere.

Ifølge redaktørene skal denne utgivelsen dekke dette. Kapitteltitlene omfatter generelle definisjoner og årsaker, genetiske og endokrinologiske årsaker, en generell oversikt over data, forskning og hypoteser knyttet til sammenhengen mellom fosterhelse og voksenhelse og konsekvenser for nevrologisk utvikling, pubertet og type 2diabetes. Det er to kapitler om betydningen av og forebygging av hemmet fostervekst i et globalt perspektiv, og tre kapitler om 
klinisk behandling i svangerskapet, av den nyfødte og av det kortvokste barnet.

Denne utgivelsen i Kargers serie Pediatric and Adolescent Medicine er en samling enkeltstående oversiktsartikler, og man yter knapt forfatterne rettferdighet ved å anmelde dem under ett. Men for boken ligger problemet her, for det er stor variasjon i kvalitet, og helheten er ikke harmonisert. I første kapittel diskuteres eksempelvis viktigheten av klare definisjoner - uten at de øvrige forfatterne synes å ha tatt dette innover seg. Kapitlene som er omtalt over står ikke i noen slik meningsfylt rekkefølge, det hele virker nærmest tilfeldig. At det er to kapitler om hemmet fostervekst i globalt perspektiv, kan mistenkes å ha vært en arbeidsulykke, for begge omhandler utbredelse, årsaker, konsekvenser og forebygging.

Hovedinnvendingen for klinikere og samfunnsmedisinere vil likevel ikke være ujevn språkføring eller varierende faglig dybde, men at dette kun glimtvis er kunnskapsbasert medisin. Av de 12 oversiktsartiklene er det kun én systematisk oversikt: om sammenhengen med type 2-diabetes. To av de tre klinisk rettede artiklene har én forfatter, mens den siste har to, som tidvis kommer med sine personlige ekspertsynspunkter, tidvis bare diskuterer problemstillinger. Av disse er det ingen systematiske oversikter, og forfatterne henviser enten sporadisk eller ikke i det hele tatt til oppsummert kunnskap som Cochrane Library. Det presenteres anbefalinger som åpenbart er i strid med kunnskapsgrunnlaget. Kapitlene om global helse gir heller intet kunnskapsbasert grunnlag for å velge de beste intervensjoner for forebygging. Klinikere bør ikke la denne utgivelsen forstyrre sin kunnskapsbaserte praksis.

Lysglimtene er knyttet til grunnforskningen, og ikke uventet til «hjertebarna» til de tre gjesteredaktørene. Genetiske årsaker til fenomenet via endokrinologiske mekanismer og IGF-1 og tilknyttede hormoners innvirkning på fosterveksten er interessant. Likeså en velskrevet oppsummering av de mange eksperimentelle studier og biologiske mekanismer som utgjør grunnlaget for «developmental origins of adult disease hypothesis». Men er dermed boken verdt sin pris?

\section{J. Frederik Frøen}

Avdeling for arv og miljø

Folkehelseinstituttet

\section{Lungemedisin i frakkelommen}

Chapman S, Robinson G, Stradling J, et al. Oxford handbook of respiratory medicine 2. utg. 856 s, tab, ill. Oxford: Oxford University Press, 2009. Pris GBP 33 ISBN 978-0-19-954516-2

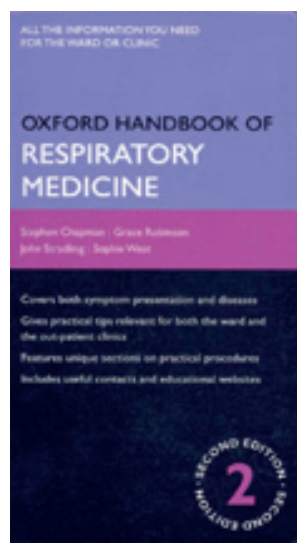

Forfatterne henvender seg til spesialistkandidater i lungemedisin og indremedisin med det som er ment som en oppslagsbok for en travel klinisk hverdag. Den er inndelt i fem deler. Den første er en presentasjon av og en oppskrift på utredning av luftveissymptomer og enkelte kliniske problemstillinger innen lungemedisinen. Del 2 er en kort presentasjon av de vanligste lungesykdommer samt lungemanifestasjoner ved enkelte indremedisinske tilstander. Del 3 er kalt Støttetiltak og er en kort oppskrift på gjennomføring av en del vanlige prosedyrer innen lungefaget, for eksempel røykeavvenning, surstoffbehandling, ikke-invasiv ventilasjonstøtte og palliativ oppfølging av terminale lungepasienter. Del 4 omhandler praktiske lungemedisinske prosedyrer. Den siste delen er et appendiks med emner som de vanligste lungefunksjonsmålinger, tolking av blodgass samt bildediagnostikk av thorax i form av røntgen og computertomografi (CT) av lungene.

Det er et bra oppslagsregister og et eget register for øyeblikkelig hjelp-problemstillinger. Når alle disse emnene er presset sammen i et format som kan få plass i frakkelommen, blir det kort. Men forfatterne har kommet godt fra denne utfordringen. Oxford handbook of respiratory medicine er konsist skrevet og meget oversiktlig. Et minus er en nesten total mangel på illustrasjoner og utredningsalgoritmer, f.eks. når det gjelder vurdering av pasienter der det er mistanke om lungeembolisme. Man savner også referanser til påstander. Bare noen av kapitlene avsluttes med anbefalinger til videre lesing. Det burde vært systematisk etter hvert kapittel. De fleste henvisningene er oppdaterte, men ikke alle. En av referansene til håndtering av et sentralt emne som kronisk obstruktiv lungesykdom (kols) er 14 år gammel.

Man kan spørre seg om det fortsatt er behov for en slik utgivelse i en tid da man kan få større oppslagsverk inn på en lommedatamaskin. Det blir en smakssak. For dem av oss som fortsatt liker å holde $i$ teksten man leser, har slike bøker fortsatt en misjon.
Oxford handbook of respiratory medicine anbefales til den oppgitte målgruppe samt til turnusleger, helsearbeidere med interesse for lungepasienter og kolleger fra andre spesialiteter med behov for et sted hvor man raskt kan sjekke lungemedisinske problemstillinger.

\section{Per Sigvald Bakke}

Lungeavdelingen

Haukeland universitetssykehus

\section{Anvendelig og aktuelt om traume- og akuttkirurgi}

Cohn SM, red.

Acute care surgery and trauma

Evidence based practice. 583 s, tab, ill. London: Informa Healthcare, 2009. Pris GBP 150 ISBN 978-1-420-07513-7

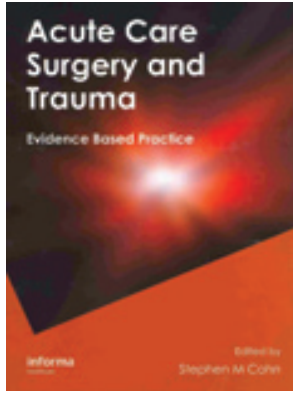

Akutt- og traumekirurgi er blitt en moderne og tidsriktig hybrid, både praktisk og akademisk, basert bl.a. på dalende interesse og redusert operativ erfaring i traumekirurgi i USA samt behov for supplerende prosedyrer og kunnskap innenfor akuttkirurgiske fagfelter hos den utrydningstruede «generelle» kirurgen. Dette er således en av flere nylig utgitte kombibøker som omhandler traume- og akuttkirurgi sammen. For norske kirurger bør dette utvilsomt være en fordel og øke aktualiteten til enkelte av disse lærebøkene. Denne er ment som et lett tilgjengelig, kunnskapsbasert oppslagsverk orientert mot diagnose- og behandlingsrelaterte problemstillinger for utdanningskandidater og spesialister i kirurgi. Innholdet dekker både traume generelt og akutte tilstander spesielt innen gastro, kar, thorax, urologi og mer «generelle» områder, og rotasjonskandidater er en velegnet målgruppe.

Tematisk er den delt $i$ tre: en del om traume, en om akutt generell kirurgi og en om kirurgiske «critical care problems». I første del gjennomgås samtlige områder innen traumatologien, og en rekke av kapitlene har tilnærmingen «kunnskapsbasert kirurgi». I del 2 omtales alt fra enterokutane fistler, perforert ulcus, ulike abdominale katastrofer, akutte karkirurgiske tilstander til appendisitt, inneklemte brokk og nekrotiserende fasciitt. Teksten er veldig klinisk orientert og innledes ofte med rammer som viser hvilke kliniske punkter som forfatterne har søkt å finne best tilgjengelig dokumentert litteratur for å svare på. Likeledes avsluttes kapitlene med anbefalinger. Det 